\title{
Rupture Process of the 1969 and 1975 Kurile Earthquakes Estimated from Tsunami Waveform Analyses
}

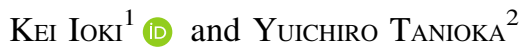

\begin{abstract}
The 1969 and 1975 great Kurile earthquakes occurred along the Kurile trench. Tsunamis generated by these earthquakes were observed at tide gauge stations around the coasts of the Okhotsk Sea and Pacific Ocean. To understand rupture process of the 1969 and 1975 earthquakes, slip distributions of the 1969 and 1975 events were estimated using tsunami waveform inversion technique. Seismic moments estimated from slip distributions of the 1969 and 1975 earthquakes were $1.1 \times 1021 \mathrm{Nm}$ $\left(M_{\mathrm{w}} 8.0\right)$ and $0.6 \times 1021 \mathrm{Nm}\left(M_{\mathrm{w}} 7.8\right)$, respectively. The 1973 Nemuro-Oki earthquake occurred at the plate interface adjacent to that ruptured by the 1969 Kurile earthquake. The 1975 Shikotan earthquake occurred in a shallow region of the plate interface where was not ruptured by the 1969 Kurile earthquake. Further, like a sequence of the 1969 and 1975 earthquakes, it is possible that a great earthquake may occur in a shallow part of the plate interface a few years after a great earthquake that occurs in a deeper part of the same region along the trench.
\end{abstract}

Key words: Tsunami waveform inversion, Kurile trench, 1969 Kurile earthquake, 1975 Shikotan earthquake.

\section{Introduction}

An interplate earthquake occurred off east Hokkaido, Japan, on August 12, 1969 (Fig. 1). The epicenter of the earthquake was $43.18^{\circ} \mathrm{N}, 147.48^{\circ} \mathrm{E}$, depth $=33 \mathrm{~km}$, with an origin time of 21:28. Abe (1973) estimated the earthquake mechanism of a pure thrust type and the seismic moment of $2.2 \times 10^{21}$ $\mathrm{Nm}\left(M_{\mathrm{w}}\right.$ 8.2) using surface waves. The moment

1 National Institute of Advanced Industrial Science and Technology, 1-1-1 Higashi, Tsukuba 305-8567, Japan. E-mail: keiioki@aist.go.jp

2 Institute of Seismology and Volcanology, Hokkaido University, N10W8 Kitaku, Sapporo 060-0810, Japan. E-mail: tanioka@mail.sci.hokudai.ac.jp release distribution of the earthquake was estimated from a body wave analysis (Schwartz and Ruff 1985, 1987). The result shows that a large moment was released near the epicenter and the estimated seismic moment was $1.8 \times 10^{21} \mathrm{Nm}\left(M_{\mathrm{w}} 8.1\right)$. Kikuchi and Fukao (1987) also estimated a time history of the moment release of the earthquake from a body wave analysis. The result shows that this event has a long duration of the moment release with the major moment release during the first $30 \mathrm{~s}$. The estimated total seismic moment was $1.4 \times 10^{21} \mathrm{Nm}$ $\left(M_{\mathrm{w}}\right.$ 8.1). A large tsunami associated with the earthquake was recorded at tide gauges around the coasts of the Okhotsk Sea and Pacific Ocean. Hatori (1970) estimated the tsunami source region (length $=170 \mathrm{~km}$ ) from arrival times of the tsunami signal. Tsunami waveform analysis of the 1969 earthquake has not been done.

The 1975 Shikotan earthquake occurred at a shallow part of the plate interface, after the 1969 earthquake which occurred at a deeper part of the same region (Fig. 1). The epicenter of the earthquake was $42.77^{\circ} \mathrm{N}, 148.22^{\circ} \mathrm{E}$, depth $=0 \mathrm{~km}$, with an origin time of 13:47. Japan Meteorological Agency estimated $M_{\text {jma }}=7.0$ using the short-period seismometers in Japan (Sapporo District Meteorological Observatory 1976). Abe (1989) estimated $M_{\mathrm{t}}=7.9$ from tsunami maximum amplitude. The 1975 earthquake was characterized as a tsunami earthquake (Takahashi 2006) as the tsunami wave is much larger than that expected from short-period seismic waves. Takemura et al. (1977) estimated a seismic moment of $2.0-3.0 \times$ $10^{20} \mathrm{Nm}\left(M_{\mathrm{w}} 7.5-7.6\right)$ using surface wave data of the 1975 earthquake. Sasatani and Kasahara (1978) estimated a seismic moment of $5.0 \times 10^{20} \mathrm{Nm}\left(M_{\mathrm{w}} 7.7\right)$ using body wave data of the 1975 earthquake. The 


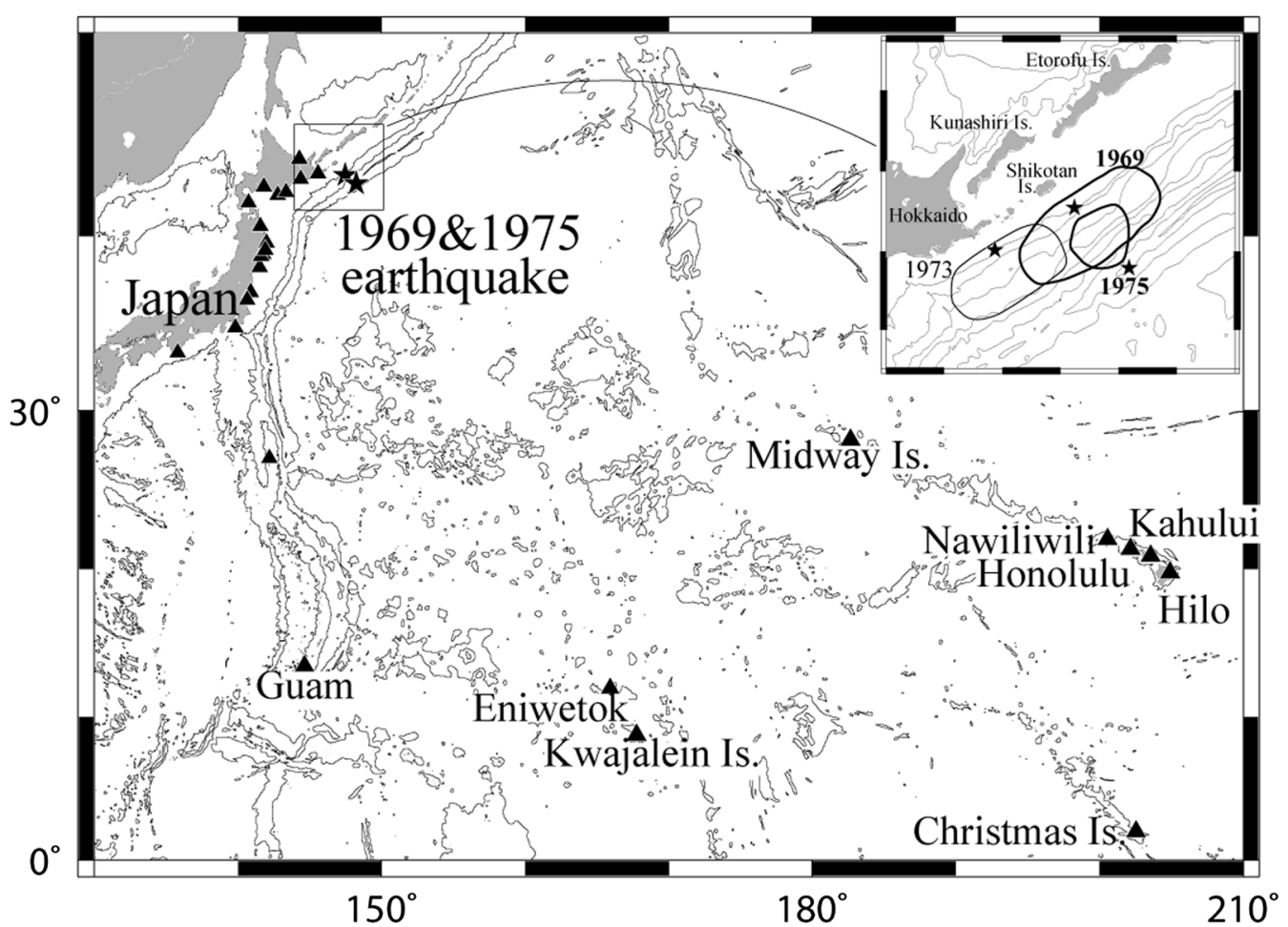

Figure 1

Location of tide gauge stations (filled triangle) used in the tsunami waveform inversion and epicenters (filled star) of the 1969 Kurile earthquake and 1975 Shikotan earthquake are shown in the Pacific Ocean. Tide gauge station names used in the tsunami waveform inversion are shown in Table 1. Aftershock areas of the 1969, 1973 and 1975 earthquakes are shown at the top right of this figure (Schwartz and Ruff 1987). The depth contour interval is $3000 \mathrm{~m}$

detailed slip distribution of the 1975 earthquake has not been estimated from previous studies and tsunami waveform analysis of the 1975 earthquake also has not been done.

The 1973 Nemuro-Oki earthquake occurred southwest of the 1969 earthquake (Fig. 1), with a seismic moment estimated to be $6.7 \times 10^{20} \mathrm{Nm}\left(M_{\mathrm{w}}\right.$ 7.8) from surface wave analysis (Shimazaki 1974). Further, slip distribution of the 1973 earthquake was estimated using tsunami waveform data, and a seismic moment of the earthquake of $6.5 \times 10^{20} \mathrm{Nm}$ $\left(M_{\mathrm{w}}\right.$ 7.8) was estimated from slip distribution (Tanioka et al. 2007). The estimated size of the rupture area of the 1973 earthquake $(80 \mathrm{~km} \times 80 \mathrm{~km})$ was obtained from the tsunami waveform inversion where the slip amount was larger than $1.0 \mathrm{~m}$.

The 1963 Kurile earthquake occurred northeast of the 1969 earthquake. Slip distribution of the 1963 earthquake was estimated using tsunami waveform data and the total seismic moment of $3.9 \times 10^{21} \mathrm{Nm}$
$\left(M_{\mathrm{w}}\right.$ 8.3) was estimated from slip distribution (Ioki and Tanioka 2011). The estimated rupture area having a slip amount of more than $1.0 \mathrm{~m}$ was $300 \mathrm{~km} \times 150 \mathrm{~km}$.

The 1994 Kurile earthquake occurred in the same area as the 1969 earthquake. However, the 1994 earthquake was an intraplate earthquake that ruptured inside the Pacific plate. The slip distribution and a seismic moment of $3.0 \times 10^{21} \mathrm{Nm}\left(M_{\mathrm{w}} 8.3\right)$ were estimated using tsunami waveform and geodetic data (Tanioka et al. 1995). The size of the rupture area of the 1994 earthquake where the slip amount was larger than $1.0 \mathrm{~m}$ on each subfault was $90 \mathrm{~km} \times 70 \mathrm{~km}$.

As described above, various types of large earthquakes occurred after the 1969 great Kurile earthquake in Kurile trench. We focus on the interplate earthquakes and studied the relationship of these rupture areas to other large earthquakes to understand a sequence of earthquakes occurred along the Kurile trench. In this study, slip distributions of 
Table 1

Tide gauge station names used in the tsunami waveform inversion of the 1969 Kurile earthquake and 1975 Shikotan earthquake

\begin{tabular}{|c|c|c|}
\hline & 1969 & 1975 \\
\hline Abashiri & 0 & 0 \\
\hline Hanasaki & $\bigcirc$ & $\bigcirc$ \\
\hline Kushiro & & \\
\hline Hiroo & 0 & 0 \\
\hline Urakawa & 0 & 0 \\
\hline Tomakomai & 0 & \\
\hline Hakodate & 0 & \\
\hline Hachinohe & 0 & $\bigcirc$ \\
\hline Miyako & $\bigcirc$ & 0 \\
\hline Kamaishi & & \\
\hline Ofunato & 0 & 0 \\
\hline Kesennuma & 0 & \\
\hline Ayukawa & O & 0 \\
\hline Onahama & 0 & 0 \\
\hline Hitachi & & 0 \\
\hline Mera & 0 & \\
\hline Kushimoto & 0 & $\bigcirc$ \\
\hline Chichijima & & 0 \\
\hline Guam & 0 & \\
\hline Eniwetok & $\bigcirc$ & \\
\hline Kwajalein & 0 & \\
\hline Midway & 0 & \\
\hline Nawiliwili & $\bigcirc$ & \\
\hline Kahului & 0 & \\
\hline Honolulu & 0 & \\
\hline Hilo & $\bigcirc$ & \\
\hline Christmas & 0 & \\
\hline
\end{tabular}

the 1969 and 1975 great Kurile earthquakes were estimated by comparing the observed tsunami waveforms at tide gauge stations with calculated waveforms. We discuss the occurrence pattern of these earthquakes by comparing the source regions of the 1969 Kurile earthquake, 1975 Shikotan earthquake and the 1973 Nemuro-Oki earthquake.

\section{Data and Fault Model}

The tsunami of the 1969 Kurile earthquake was observed at more than 23 tide gauge stations. For this study, tsunami waveform data from 14 tide gauge stations in Japan and 9 tide gauge stations in the Pacific Ocean were used. In the case of the tsunami of the 1975 Shikotan earthquake, tsunami waveform data from 14 tide gauge stations in Japan were used (Fig. 1; Table 1). Tsunami waveform data in Japan have been collected from the Tsunami Chart Data along the coast of Japan (1899-1969) published by Japan Weather Association. Other tsunami waveform data of the Pacific Ocean have been collected from the NGDC-NOAA (http://www.ngdc.noaa.gov/ hazard/tide.shtml). Tsunami waveforms that were observed at each tide gauge station included tsunami signals and tide signals. We calculated tide signals from the observed waveforms of average of each $3 \mathrm{~h}$. Tsunami signals were obtained from subtracting calculated tide signals from observed waveforms.

For the 1969 Kurile earthquake, the earthquake mechanism is assumed to be a pure thrust type. Dip angle of the fault model, $25^{\circ}$, was assumed based on the angle of the subducting Pacific plate in the Kurile trench. Strike of the fault model, $230^{\circ}$, was determined from the direction of the Kurile trench axis. Abe (1973) indicated that length and width of the rupture area of the 1969 earthquake were 180 and $85 \mathrm{~km}$, respectively, from aftershocks within 1 day. For this study, 12 subfaults were allocated to cover this aftershock area; the size of each subfault is $50 \mathrm{~km} \times 50 \mathrm{~km}$, and the location of subfaults is shown in Fig. 2 a.

For the 1975 Shikotan earthquake, the earthquake mechanism is thrust type which occurred on very shallow part of the interplate close to the trench axis. Dip angle of $10^{\circ}$ and strike of $230^{\circ}$ were assumed in the fault model. The size of aftershock area of the 1975 earthquake is $100 \mathrm{~km} \times 60 \mathrm{~km}$ along plate interface near the Kurile trench (Takahashi, 2006). For this study, 8 subfaults were allocated to cover the aftershock area estimated from Schwartz and Ruff (1987); the size of each subfault is $50 \mathrm{~km} \times 60 \mathrm{~km}$, and the location of subfaults is shown in Fig. 2 b.

\section{Tsunami Waveform Inversion}

One arc-min of gridded bathymetry data by GEBCO was selected to calculate propagation of the tsunami. A finer grid size of 20 arc-sec was selected near the tide gauge stations. The bathymetric data of 20 arc-sec near Japan were interpolated from MIRCJTOPO 30. The bathymetric data of 20 arc-sec of the Pacific Ocean were created by digitizing NAUTCAL CHARTS. The tsunami computed area is $130^{\circ}-$ $220^{\circ} \mathrm{E}, 0^{\circ}-60^{\circ} \mathrm{N}$. 


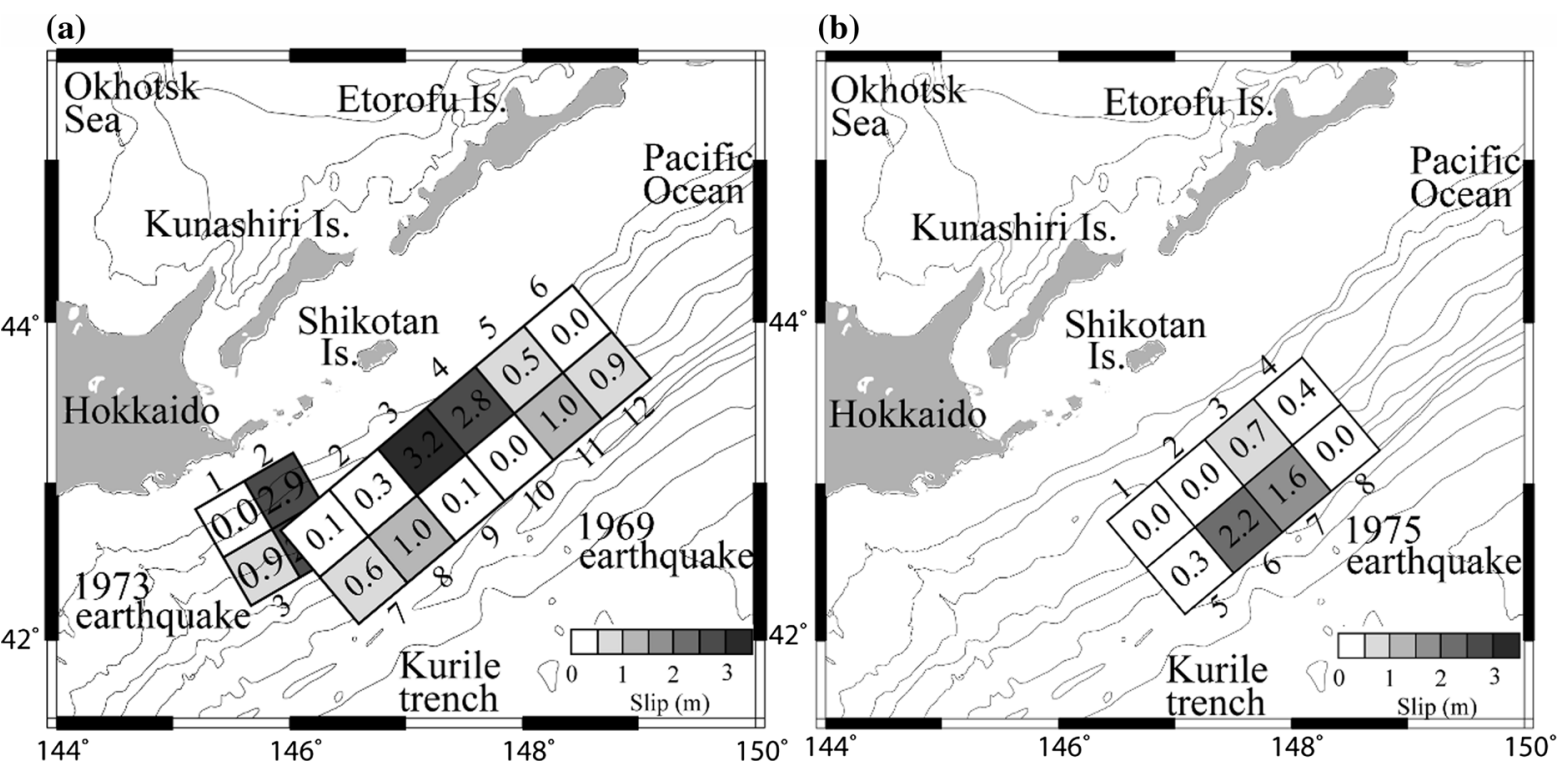

Figure 2

a Slip distribution of the 1969 Kurile earthquake estimated from the tsunami waveform inversion. The size of each subfault is $50 \mathrm{~km} \times 50 \mathrm{~km}$. Slip distribution of the 1973 Nemuro-Oki earthquake was estimated from tsunami waveform analysis by Tanioka et al. (2007). The size of each subfault is $40 \mathrm{~km} \times 40 \mathrm{~km}$. b Slip distribution of the 1975 Shikotan earthquake estimated from the tsunami waveform inversion. The size of each subfault is $50 \mathrm{~km} \times 60 \mathrm{~km}$. The number inside of rectangle shows slip amount on each subfault and the unit of slip amount is meter. The number outside of rectangle shows a subfault number on each subfault. The depth contour interval is $1000 \mathrm{~m}$

The initial condition of the tsunami must be calculated, before calculating the propagation of the tsunami. On each subfault, coseismic deformation on the seafloor was computed using Okada's formula (Okada 1985). We assumed that initial water deformation on the sea surface was equal to coseismic deformation on the seafloor. If a depth of the sea is much smaller than wavelength of the initial water deformation, this assumption is allowed. We solved the linear shallow water equations including the Coriolis term using the finite difference method with a staggered grid system (Satake 2007). To satisfy a stability condition, the time step was chosen to be $1 \mathrm{~s}$. The total reflection boundary was used at the coastline and the open boundary was used at the end of the computed area.

We used tsunami waveforms calculated from a unit amount of slip on each subfault as Green's function of tsunami waveform inversion. The tsunami inversion method is described in detail by Satake (2007). Non-negative constraints were applied to the slip amount on each subfault. We used the first few cycles of tsunami waveforms to eliminate later phases including reflected waves. We used the jackknife technique (Tichelaar and Ruff 1989) for error analysis. To calculate the standard deviation of slip amount, inversion was repeated by dropping some data randomly from the original data.

\section{Results}

The slip distribution and calculated errors of the slip amount on each subfault of the 1969 great Kurile earthquake are shown in Fig. 2a and Table 2. The result indicates that the maximum slip amount is $3.2 \mathrm{~m}$ in subfault 3 and the next largest slip amount is $2.8 \mathrm{~m}$ in subfault 4 . These subfaults having a large slip amount are located at near the epicenter of the 1969 earthquake, at the deep central part of the rupture area. The major slip region in which slip amount is larger than $1.0 \mathrm{~m}$ on each subfault is located off Shikotan Island. The size of the rupture area in the major region is $200 \mathrm{~km}$ in length and $100 \mathrm{~km}$ in width. This major region is similar to the aftershock area within 1 day (Abe 1973), the source region 
Table 2

Slip and error on each sub fault of the 1969 Kurile earthquake

\begin{tabular}{lll}
\hline Subfault number & Slip $(\mathrm{m})$ & Error $(\mathrm{m})$ \\
\hline 1 & 0.1 & 0.1 \\
2 & 0.3 & 0.3 \\
3 & 3.2 & 0.5 \\
4 & 2.8 & 0.8 \\
5 & 0.5 & 0.5 \\
6 & 0.0 & 0.0 \\
7 & 0.6 & 0.2 \\
8 & 1.0 & 0.3 \\
9 & 0.1 & 0.3 \\
10 & 0.0 & 0.2 \\
11 & 1.0 & 0.4 \\
12 & 0.9 & 0.5 \\
\hline
\end{tabular}

calculated from $\mathrm{P}$ wave data (Schwartz and Ruff 1985) and arrival times of the tsunami signal (Hatori 1970). The location of the subfault 3 and subfault 4 having a large slip amount is almost same as the location where many aftershock occurred and moment release that estimated from seismic waveform analysis was large (Schwartz and Ruff 1985; Kikuchi and Fukao 1987). The seismic moment of $1.1 \times 10^{21} \mathrm{Nm}\left(M_{\mathrm{w}} 8.0\right)$ was computed from the slip distribution of the 1969 earthquake. The rigidity was assumed to be $4.0 \times 10^{10} \mathrm{~N} / \mathrm{m}^{2}$. The seismic moment in our result is similar to the seismic moment calculated from seismological studies by Abe (1973), Kikuchi and Fukao (1987), and Schwartz and Ruff (1987). Calculated tsunami waveforms of the 1969 earthquake were compared with the observed ones (Fig. 3). The double amplitude of $1 \mathrm{~m}$ or more was recorded at the coast of eastern Hokkaido. Computed waveforms are closely matched the observed waveforms.

The 1973 Nemuro-Oki earthquake ruptured the southwest side of the 1969 earthquake rupture area. The major slip region of the 1973 earthquake as estimated from the tsunami waveform analysis (Tanioka et al. 2007) is located in subfault 2 and subfault 4 where the slip amount of the 1969 earthquake is almost negligible (subfault 1) (Fig. 2a; Table 3). This suggests that the 1973 earthquake ruptured the plate interface immediately adjacent to the location ruptured by the 1969 earthquake.

The slip distribution and calculated errors of the slip amount on each subfault of the 1975 Shikotan earthquake are shown in Fig. $2 \mathrm{~b}$ and Table 4. The large slip amount of $2.2 \mathrm{~m}$ and $1.6 \mathrm{~m}$ can be seen in subfault 6 and subfault 7 . Because these slip amount are much larger than errors of slip amount, it is reliable that these subfaults ruptured with a large slip. Errors of slip amounts for the 1975 earthquake are similar to those for the 1969 earthquake although the number of tsunami waveforms used in those inversions is different. Therefore, slip distributions of the 1969 and 1975 earthquakes can be compared with similar resolutions. The size of the rupture area having a slip amount of more than $1 \mathrm{~m}$ is $100 \mathrm{~km}$ in length and $60 \mathrm{~km}$ in width. The aftershock area estimated from Schwartz and Ruff (1987) is same at the rupture area and located in subfault 6 and subfault 7 where the slip amount of the 1969 earthquake is almost negligible in subfault 9 and subfault 10 . This result indicates that the shallow region of the plate interface was not ruptured by the 1969 earthquake, but was later ruptured by the 1975 tsunami earthquake. The seismic moment of $0.6 \times 10^{21} \mathrm{Nm}\left(M_{\mathrm{w}}\right.$ 7.8) was calculated from the slip distribution of the 1975 earthquake assuming that the rigidity is $4.0 \times 10^{10} \mathrm{~N} / \mathrm{m}^{2}$. The calculated seismic moment is slightly larger or similar to the seismic moment estimated from seismic waveform analyses by Takemura et al. (1977) and Sasatani and Kasahara (1978). Calculated tsunami waveforms of the 1975 earthquake were compared with the observed ones (Fig. 4). Calculated waveforms matched the observed waveforms in Japan.

\section{Discussion}

Because Japan Meteorological Agency estimated $M_{\text {jma }}=7.0$ using the short-period seismometers in Japan (Sapporo District Meteorological Observatory 1976) and Abe (1989) estimated $M_{\mathrm{t}}=7.9$ from tsunami maximum amplitude, the 1975 earthquake was characterized as a tsunami earthquake. In this study, $M_{\mathrm{w}}$ of the 1975 earthquake was estimated from the tsunami waveform analysis to be 7.8 which is similar to the estimate from the body wave analysis by Sasatani and Kasahara (1978) of 7.7. This suggests that tsunami from the 1975 tsunami earthquake could be well predicted if the magnitude was estimated 

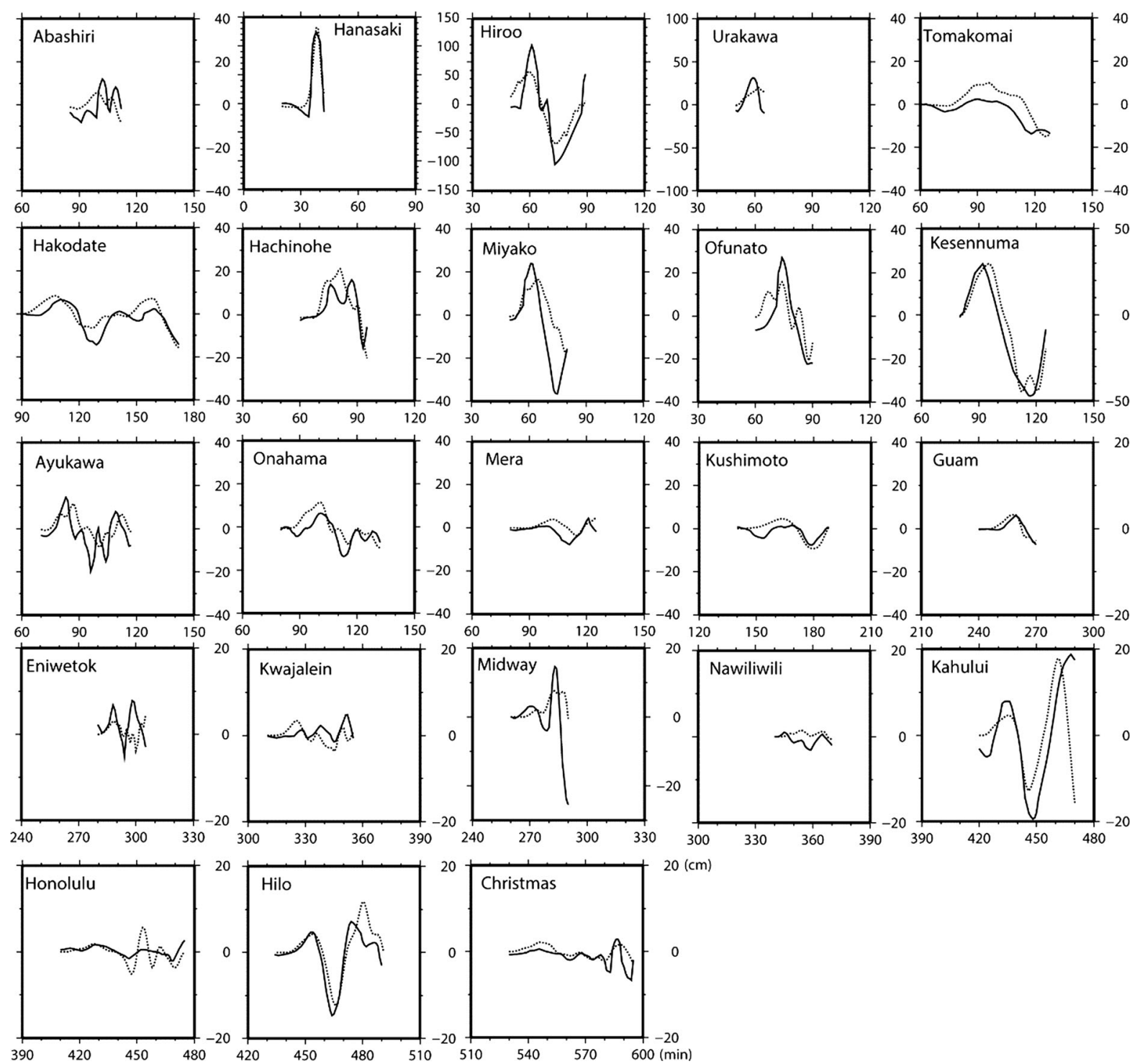

Figure 3

Comparison of observed (solid line) and computed (dotted line) tsunami waveforms of the 1969 Kurile earthquake at 23 tide gauge stations. Tsunami waveforms of time window used in the tsunami waveform inversion are shown. Horizontal axis is time (min) from the origin time of the 1969 Kurile earthquake and vertical axis is amplitude $(\mathrm{cm})$

Table 3

Slip and error on each subfault of the 1973 Neuro-Oki earthquake estimated from Tanioka et al. (2007)

\begin{tabular}{lll}
\hline Subfault number & Slip $(\mathrm{m})$ & Error $(\mathrm{m})$ \\
\hline 1 & 0.0 & 0.0 \\
2 & 2.9 & 0.4 \\
3 & 0.9 & 0.2 \\
4 & 2.9 & 0.4 \\
\hline
\end{tabular}

using a long-period body wave analysis. Tsunami earthquakes of this scale same as the 1975 earthquake may be detected by seismic waveform analyses.

A similar sequence of earthquakes is shown in the next region of the 1969 earthquake along the Kurile trench. The 1963 great Kurile earthquake occurred at a deep part of the plate interface. The largest aftershock of the 1963 earthquake occurred at a shallow 
Table 4

Slip and error on each subfault of the 1975 Shikotan earthquake

\begin{tabular}{lll}
\hline Sub fault number & Slip (m) & Error $(\mathrm{m})$ \\
\hline 1 & 0.0 & 0.0 \\
2 & 0.0 & 0.0 \\
3 & 0.7 & 0.3 \\
4 & 0.4 & 0.2 \\
5 & 0.3 & 0.4 \\
6 & 2.2 & 0.4 \\
7 & 1.6 & 0.4 \\
8 & 0.0 & 0.0 \\
\hline
\end{tabular}

part of the plate interface 7 days after the 1963 mainshock (Ioki 2013).

A similar sequence of earthquakes is also shown in the Sunda trench, Indonesia. In 2007, the Bengkulu earthquake occurred along the Sunda trench. Slip distribution of the 2007 Bengkulu earthquake was estimated using tsunami waveform data and InSAR data (Gusman et al. 2010), and showed that the 2007 earthquake ruptured a deep part of the subducting plate. Subsequently, in 2010, the Mentawai tsunami earthquake occurred. Slip distribution of the 2010
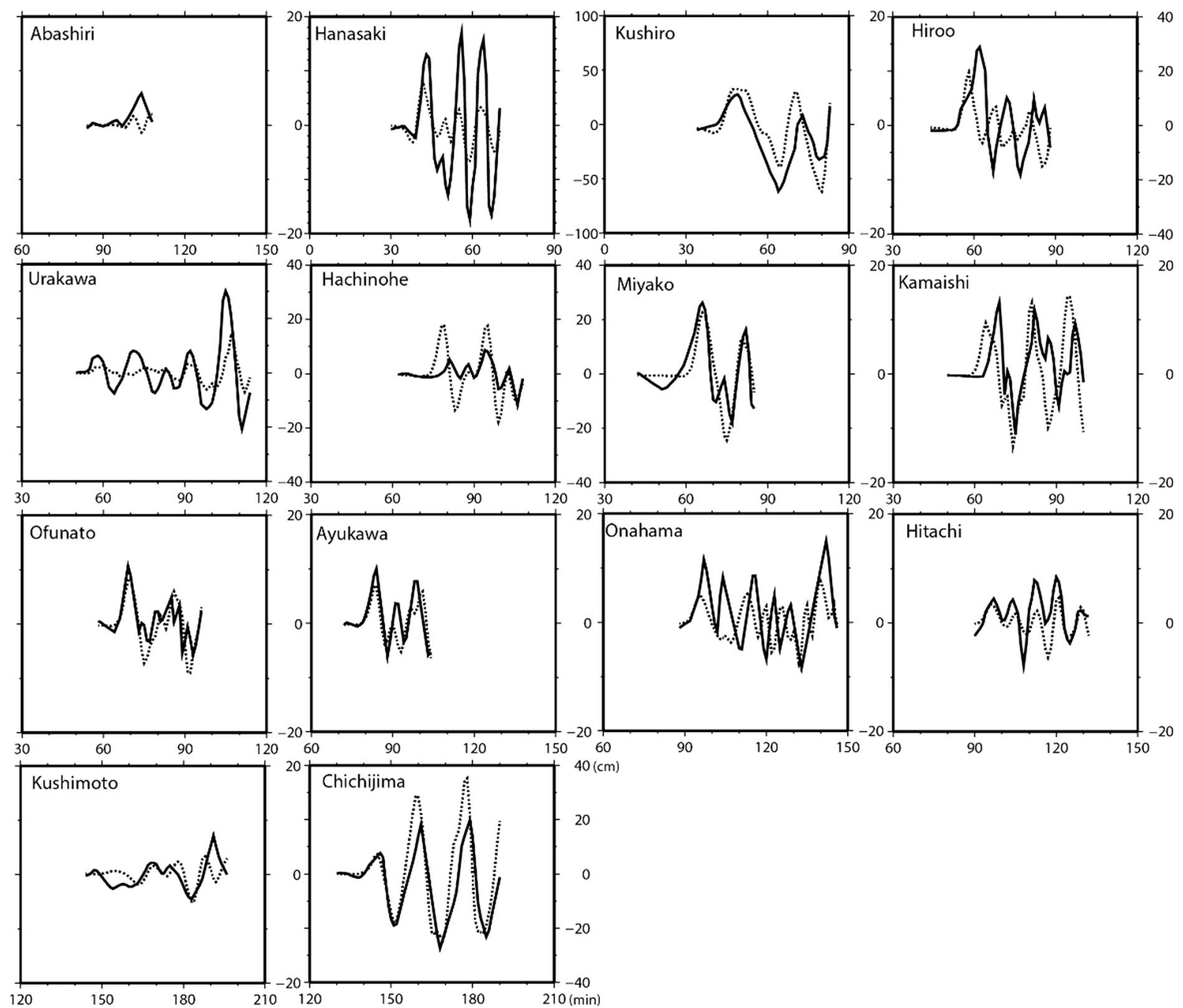

Figure 4

Comparison of observed (solid line) and computed (dotted line) tsunami waveforms of the 1975 Shikotan earthquake at 14 tide gauge stations. Tsunami waveforms of time window used in the tsunami waveform inversion are shown. Horizontal axis is time (min) from the origin time of the 1975 Shikotan earthquake and vertical axis is amplitude $(\mathrm{cm})$ 
Mentawai earthquake was estimated from tsunami waveform inversion (Satake et al. 2013) and showed that the 2010 earthquake ruptured a shallow part of the subducting plate that had not been ruptured by the 2007 earthquake. Lay et al. (2012) define domains of seismogenic behavior along the megathrust from the trench to the down dip edge. A shallowest portion, less than $15 \mathrm{~km}$ below sea level, was designated as the portion that tsunami earthquakes occur. The 2010 Mentawai earthquake was defined as the earthquake occurred at the shallow portion. The middle depth portion from 15 to $35 \mathrm{~km}$ was designated that typical large earthquakes occur. The 2007 Bengkulu earthquake was defined as the earthquake occurred at the middle portion.

It appears that, in both the Kurile trench and Sunda trench, a large earthquake occurred in a shallow region after a great earthquake occurred in a deeper region in the same area along the trench. Sun et al. (2014) found that crustal deformation continuously occurs after a large thrust earthquake such as the 2011 Tohoku-Oki earthquake and this postseismic deformation is due to viscoelastic relaxation of stresses. After the thrust earthquake occurring in a deep part of the plate interface, by the effect of viscoelastic relaxation in short term, it may be possible that a shear stress is continuously accumulated in a shallow part of the same plate interface and eventually causes the large earthquake as a tsunami earthquake. Miyazaki et al. (2004) found that most afterslip of the 2003 Tokachi-Oki earthquake occurs outside the coseismic rupture zone including updip portion. Hsu et al. (2006) also found that the 2005 Nias-Simeulue earthquake triggered aseismic afterslip on the subduction megathrust in updip direction from the main rupture. Thus, the effect of afterslip also may contribute to the stress accumulation in a shallow part of the plate interface.

As shown above, although time scales of the delay times show the large variety, large earthquakes occurred in a shallow region after great earthquakes occurred in a deep region in the same area along the trench by the effects of the viscoelastic relaxation and afterslip.

\section{Conclusion}

The slip distribution of the 1969 great Kurile earthquake was estimated using tsunami waveform inversion. Our results indicate that the major slip region of the 1969 earthquake was located near the epicenter and the area where many aftershocks occurred. The seismic moment of the 1969 earthquake is $1.1 \times 10^{21} \mathrm{Nm}\left(M_{\mathrm{w}} 8.0\right)$. The source area obtained from the slip distribution is similar to the aftershock area within 1 day and the source area estimated from previous study using $\mathrm{P}$ waves. The 1973 Nemuro-Oki earthquake ruptured adjacent to the rupture area of the 1969 earthquake.

The slip distribution of the 1975 Shikotan earthquake was also estimated from tsunami waveform analysis. The seismic moment of the 1975 earthquake is $0.6 \times 10^{21} \mathrm{Nm}\left(M_{\mathrm{w}} 7.8\right)$. This seismic moment is similar to the seismic moment estimated from previous studies using seismic waveforms. The source area obtained from the slip distribution is similar to the aftershock area within 1 month.

The 1975 Shikotan earthquake ruptured a shallow part of the plate interface, after the 1969 Kurile earthquake that ruptured a deeper part of the same region. The 1975 earthquake ruptured the plate interface which was not ruptured by the 1969 earthquake. The occurrences of the 1969 earthquake and 1975 earthquake suggest a possible pattern that a great earthquake may occur in a shallow region a few years after a great earthquake which occurs in a deep region along the trench.

\section{Acknowledgments}

We would like to thank two anonymous referees and Eric Geist for their helpful comments and suggestions. This study was supported by the Ministry of Education, Culture, Sports, Science and Technology (MEXT) of Japan, under its Earthquake and Volcano Hazards Observation and Research Program. This work was supported by JSPS KAKENHI Grant Number 24241060. 
Open Access This article is distributed under the terms of the Creative Commons Attribution 4.0 International License (http:// creativecommons.org/licenses/by/4.0/), which permits unrestricted use, distribution, and reproduction in any medium, provided you give appropriate credit to the original author(s) and the source, provide a link to the Creative Commons license, and indicate if changes were made.

\section{REFERENCES}

Abe, K. (1973). Tsunami and mechanism of great earthquakes. Physics of the Earth and Planetary Interiors, 7, 143-153.

Abe, K. (1989). Quantification of tsunamigenic earthquakes by the Mt scale. Tectonophysics, 166, 27-34.

Gusman, A. R., Tanioka, Y., Kobayashi, T., Latief, H., \& Pandoe, W. (2010). Slip distribution of the 2007 Bengkulu earthquake inferred from tsunami waveforms and InSAR data. Journal Geophysical Research, 115, B12316. doi:10.1029/2010JB007565.

Hatori, T. (1970). An Investigation of the Tsunami generated by the East Hokkaido Earthquake of August, 1969. Bulletin of the Earthquake Research Institute, 48, 399-412.

Hsu, Y., Simons, M., Avouac, J., Galetzka, J., Sieh, K., Chlieh, M., Natawidjaja, D., Prawirodirdjo, L., \& Bock, Y. (2006). Frictional Afterslip Following the 2005 Nias-Simeulue Earthquake, Sumatra, Science, 312, 1921-1926.

Ioki, K. (2013). Source process of great earthquakes along the Kurile trench estimated from tsunami waveforms and tsunami deposit data, Doctoral thesis, Graduate school of Science, Hokkaido University.

Ioki, K., \& Tanioka, Y. (2011). Slip distribution of the 1963 Great Kurile Earthquake Estimated from Tsunami Waveforms. Pure and Applied Geophysics, 168, 1045-1052.

Kikuchi, M., \& Fukao, Y. (1987). Inversion of long-period P waves from great earthquakes along subduction zones. Tectonophysics, 144, 231-247.

Lay, T., Kanamori, H., Ammon, C. J., Koper, K. D., Hutko, A. R., Ye, L., et al. (2012). Depth-varying rupture properties of subduction zone megathrust faults. Journal Geophysical Research, 117, B04311. doi:10.1029/2011JB009133.

Miyazaki, S., Segall, P., Fukuda, J., \& Kato, T. (2004). Space time distribution of afterslip following the 2003 Tokachi-oki earthquake: implications for variations in fault zone frictional properties. Geophysical Reseach Letters,. doi:10.1029/2003 GL019410.
Okada, Y. (1985). Surface deformation due to shear and tensile faults in a half-space. Bulletin of the seismological society of America, 75, 1135-1154.

Sapporo District Meteorological Observatory (1976), Report on the Earthquake Off E coast of Hokkaido, in Japanese.

Sasatani, T., \& Kasahara, M. (1978). Analysis of Strain Seismograms from Near Earthquakes, Jishin, 2(31), 11-23, in Japanese (abstract is in English).

Satake, K. (2007), Tsunamis, in "Treatise on Geophysics Volume 4: Earthquake Seismology”, ed. by H. Kanamori, Elsevier Science, pp. 483-512.

Satake, K., Nishimura, Y., Putra, P. S., Gusman, A. R., Sunendar, H., Fujii, Y., et al. (2013). Tsunami Source of the 2010 Mentawai, Indonesia Earthquake Inferred from Tsunami Field Survey and Waveform Modeling. Pure and Applied Geophysics, 170, 1567-1582. doi:10.1007/s00024-012-0536-y.

Schwartz, S. Y., \& Ruff, L. J. (1985). The 1968 Tokachi-Oki and the 1969 Kurile Islands earthquakes: variability in the rupture process. Journal Geophysical Research, 90, 8613-8626.

Schwartz, S. Y., \& Ruff, L. J. (1987). Asperity distribution and earthquake occurrence in the southern Kurile Arc. Physics of the Earth and Planetary Interiors, 49, 54-77.

Shimazaki, K. (1974). Nemuro-Oki Earthquake of June 17, 1973: a Lithospheric Rebound at the Upper Half of the Interface. Physics of the Earth and Planetary Interiors, 9, 314-327.

Sun, T., Wang, K., Iinuma, T., Hino, R., He, J., Fujimoto, H., et al. (2014). Prevalence of viscoelastic relaxation after the 2011 Tohoku-oki earthquake. Nature, 514, 84-87. doi:10.1038/ nature 13778 .

Takahashi, H. (2006). Characteristics of a Tsunami Earthquake Occurring in Hokkaido-Revisiting the Hokkaido-Toho-Oki Earthquake on June10, 1975-, Geophysical Bulletin of Hokkaido University, 69, 207-220, in Japanese (abstract is in English).

Takemura, M., Koyama, J., \& Suzuki, Z. (1977). Source process of the 1974 and 1975 earthquakes in Kurile Islands in special relation to the differences in excitation of tsunami, Science Reports of the Tohoku University., 5(24), 113-132.

Tanioka, Y., Ruff, L. J., \& Satake, K. (1995). The great Kurile earthquake of October 4, 1994 tore the slab. Geophysical Reseach Letters, 22(13), 1661-1664.

Tanioka, Y., Satake, K., \& Hirata, K. (2007). Recurrence of Recent Large Earthquakes Along the Southernmost Kurile-Kamchatka Subduction Zone. Geophysical monograph, 172, 145-152.

Tichelaar, B. W., \& Ruff, L. J. (1989). How good are our best model? Jackknifing, bootstrapping, and earthquake depth, EOS, 70(593), 605-606.

(Received July 3, 2016, revised September 9, 2016, accepted September 13, 2016, Published online September 23, 2016) 